\title{
Human immunodeficiency virus infection and cardiovascular risk
}

\author{
Erzsébet Iringó Zaharia-Kézdi ${ }^{1 *}$, Carmen Chiriac', Andrea Incze', Nina Șincu', Előd Nagy², Ildikó Dósa ${ }^{3}$ \\ From The 10th Edition of the Scientific Days of the National Institute for Infectious Diseases "Prof Dr Matei \\ Bals" \\ Bucharest, Romania. 15-17 October 2014
}

\section{Background}

Cardiovascular diseases are the second leading non-AIDS dependent cause of mortality for human immunodeficiency virus-infected (HIV) patients. Thus, the evaluation of cardiovascular risk factors (CVRF) and the identification of persons at risk are necessary for the implementation of prevention methods.

\section{Methods}

A retrospective cross-sectional study was performed on a group of $50 \mathrm{HIV}$ patients at the I Clinic of Infectious

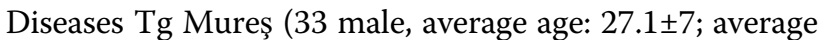
duration of antiretroviral treatment: $11.16 \pm 6.88$ years; average TCD4+ lymphocyte (LTCD4+) count on last evaluation: $593.98 \pm 392.55$ cells/ $\mu \mathrm{L} ; 38$ in AIDS stage). From the moment of diagnosis until July 2014, several classic CVRF have been studied: age, sex, smoking, obesity, dyslipidemia, diabetes, hypertension and global cardiovascular risk (CVR) estimated with Framingham score. The results were correlated with: antiretroviral treatment (ART), the number of ART combinations, LTCD4+ and hepatitis B (HBV) coinfection. For statistical analysis the Student and Mann-Whitney tests were used with $95 \%$ confidence interval and statistical significance $\mathrm{p}<0.05$.

\section{Results}

CVRF: hypertriglyceridemia, 29 patients (22 in stage C), decreased high-density lipoproteins (HDL) 23 (elevated, 10), hypercholesterolemia 12 , elevated low-density lipoprotein (LDL) 7, smoking habit 16 , obese 3 , overweight 5 , underweight 8 , hypertension 2 , diabetes 1 . The Framingham test global scores: 6 moderate, 1 elevated, 43 decreased. A significant statistical difference can be observed between the initial and final values of: total cholesterol (TC), LDL and triglycerides (TG) $\mathrm{p}=0.0002$, $\mathrm{p}=0.0495, \mathrm{p}=0.0002$. Patients with $\geq 3$ combinations of ART had a significantly larger average value of TC, LDL and TG ( $\mathrm{p}=0.030, \mathrm{p}=0.041, \mathrm{p}=0.027)$ compared to those with 1 combination.

Significant statistical differences are registered between: average TC and TG values $(\mathrm{p}=0.0001 \mathrm{p}=0.0013)$ depending on the treatment with or without protease inhibitors (PI); between HDL values for patients with LTCD4+ $\geq 500$ cells $/ \mu \mathrm{L}$ and those with TCD $4+<500$ cells $/ \mu \mathrm{L}(\mathrm{p}=0.028)$. Average TG values were significantly higher for HBV coinfections $(\mathrm{p}=0.0349)$.

\section{Conclusion}

The most frequent CVRF were: hypertriglyceridemia (58\%), fall of HDL levels (46\%), smoking (32\%), hypercholesterolemia (24\%), decreased LDL levels (14\%). The lipid levels are influenced by: type of ART, number of combinations, presence of HBV and the advanced stage of disease. High levels of LTCD4+ and HDL can be considered protective factors. Because of the existence of these risks, the initiation of a program for the reduction of cardiovascular risks is necessary.

\footnotetext{
Authors' details

${ }^{1}$ Clinic of Infectious Diseases I, University of Medicine and Pharmacy Tîrgu Mureş, Romania. ${ }^{2}$ County Hospital Laboratory, University of Medicine and Pharmacy Tîrgu Mureş, Romania. ${ }^{3}$ University of Medicine and Pharmacy Tîrgu Mureş, Romania.
}

Published: 15 October 2014

* Correspondence: ezahariakezdi@yahoo.com

${ }^{1}$ Clinic of Infectious Diseases I, University of Medicine and Pharmacy Tîrgu

Mureş, Romania

Full list of author information is available at the end of the article 
doi:10.1186/1471-2334-14-S7-P83

Cite this article as: Zaharia-Kézdi et al:: Human immunodeficiency virus

infection and cardiovascular risk. BMC Infectious Diseases 2014

14(Suppl 7):P83.

Submit your next manuscript to BioMed Central and take full advantage of:

- Convenient online submission

- Thorough peer review

- No space constraints or color figure charges

- Immediate publication on acceptance

- Inclusion in PubMed, CAS, Scopus and Google Scholar

- Research which is freely available for redistribution

Submit your manuscript at 